\title{
Relationship between the timing of the first postpartum ovulation and antral follicle counts in Holstein cows
}

\author{
Eri Furukawa ${ }^{1}$, Tomoyuki Masaki ${ }^{1}$, Kenichiro Sakaguchi ${ }^{1}$, Min Bo $^{2}$, Yojiro Yanagawa ${ }^{3}$, Koichiro Ueda ${ }^{4}$ and \\ Masashi Nagano ${ }^{3,5^{*}}$ (i)
}

\begin{abstract}
Background: The timing of the first postpartum ovulation is an important factor affecting the timing of estrous resumption in dairy cows. The first postpartum ovulation is delayed in cows producing large amounts of milk with an intensive negative energy balance. The antral follicle count (AFC) and serum anti-Müllerian hormone concentrations are known to be indicators of the ovarian reserve, which is the number and quality of follicles left in a pair of ovaries and known as an indicator of female fertility. Cows with higher AFC have been proven to show higher pregnancy rate and shorter calving to conception intervals; however, the relationship between the timing of the first postpartum ovulation and ovarian reserve remains unclear. Therefore, this study examined the relationships between postpartum follicular dynamics, the ovarian cycle, nutritional status, and ovarian reserve.
\end{abstract}

Methods: Transrectal ultrasonography was conducted from calving to 70-120 days in milk (DIM) in 26 cows to monitor AFC, follicular dynamics and the ovarian cycle. Body weight (BW) and milk yield were used as indicators of nutritional status.

Results: The first postpartum ovulation was significantly later in cows with low AFC $(<25)$ than in those with high AFC ( $\geq 25)$, while changes in BW from calving to the nadir and milk production were similar in both groups. The present results also suggested that cows with low AFC and a delayed first postpartum ovulation had a shorter first ovarian cycle after the first postpartum ovulation. The mean DIM of the first postpartum artificial insemination (AI) and days open (days from calving to Al with which pregnancy was achieved) were similar in high and low AFC groups.

Conclusions: The first postpartum ovulation was significantly earlier in cows with high AFC than in those with low AFC. The assumed reason for this result was higher sensitivity to luteinizing hormone and larger androstenedione and estradiol production in follicles in high AFC cows. Therefore, cows with high AFC may be more fertile than those with low AFC while their milk production increase and BW decrease; it means they are in negative energy balance.

(340/350 words)

Keywords: Antral follicle count, First postpartum ovulation, Ovarian reserve, Ultrasonography

* Correspondence: mnaga@vmas.kitasato-u.ac.jp

${ }^{3}$ Laboratory of Theriogenology, Faculty of Veterinary Medicine, Hokkaido

University, Sapporo 060-0818, Japan

${ }^{5}$ Laboratory of Animal Reproduction, Department of Animal Science, School

of Veterinary Medicine, Kitasato University, Towada 034-8628, Japan

Full list of author information is available at the end of the article

(c) The Author(s). 2020 Open Access This article is distributed under the terms of the Creative Commons Attribution 4.0 International License (http://creativecommons.org/licenses/by/4.0/), which permits unrestricted use, distribution, and reproduction in any medium, provided you give appropriate credit to the original author(s) and the source, provide a link to the Creative Commons license, and indicate if changes were made. The Creative Commons Public Domain Dedication waiver (http://creativecommons.org/publicdomain/zero/1.0/) applies to the data made available in this article, unless otherwise stated. 


\section{Background}

In cattle, a surge in the secretion of follicle-stimulating hormone (FSH) occurs 4-5 days after parturition [1], and the first follicular wave then emerges. A dominant follicle of the first follicular wave results in ovulation, regression, or cyst formation [2]. If the first dominant follicle ovulates, an ovarian cycle accompanied with corpus luteum (CL) formation resumes. In cases in which the first dominant follicle degenerates, second and more follicular waves repeat emergence, growth, and regression until the first ovulation occurs [2]. Since there is no CL or progesterone secretion at the time of the first ovulation, most cows do not exhibit estrous symptoms and only approximately $10 \%$ of cows show standing estrus [3]. However, in the second ovulation after the first ovarian cycle, which is defined as the period from the first to second postpartum ovulation accompanied by CL formation [4], the proportion of cows exhibiting estrous symptoms increases to $40 \%$ [3]. These findings indicate that the opportunity for first artificial insemination (AI) based on estrus detection is delayed when the time of the first postpartum ovulation becomes later in days in milk (DIM). Therefore, the resumption of an ovarian cycle is important for reproductive management in cattle.

In dairy cows, the main factor affecting the resumption of an ovarian cycle is the energy balance $[5,6]$. Cows with a negative energy balance (NEB) show a suppressed frequency of gonadotropin-releasing hormone (GnRH) pulses, a shortage of luteinizing hormone (LH) pulse frequencies, and lower estradiol production, which lead to anovulatory dominant follicles [7]. In contrast, the dominant follicle in cows with a smaller NEB may ovulate earlier postpartum. The energy intake and milk yield interaction affects the energy balance in cows, and changes in the body condition score (BCS) and body weight (BW) reflect changes in nutritional status. Previous studies reported that the first postpartum ovulation was delayed in cows with acute BCS loss [5] and greater $\mathrm{BW}$ loss [8]. Since BW is not affected by differences in the technician evaluations and postpartum BW loss is not affected by parity [9], BW may be a more objective parameter than BCS. Advances in genetics and management in dairy farms have progressed rapidly in the last few decades and milk yield has recently increased; therefore, NEB in postpartum cows is becoming larger. More cows showed delayed first ovulation in 1998 than in 1986 because of the higher proportion of NEB cattle [10]. The proportion of cows remaining anovular during the voluntary waiting period (VWP, 50-65 DIM) was reported to be $5-40 \%$ [11-13].

The ovarian reserve, which is defined as the number and quality of follicles left in a pair of ovaries at any given time [14], is an indicator of female fertility in mono-ovulatory species, such as humans [14] and cattle [15]. Although it is not possible to directly measure the primordial follicle pool in the ovaries, the antral follicle count (AFC), which is the number of antral follicles in a pair of ovaries counted by ultrasonography, and the plasma concentration of anti-Müllerian hormone $(\mathrm{AMH})$ are indicators of the ovarian reserve. AFC has been shown to positively correlate with the number of primordial follicles in the ovaries [16]. AMH is a hormone that functions to suppress the outgrowth of primordial follicles [17] and its expression has been observed in the granulosa cells of growing preantral and antral follicles [18]. Plasma AMH concentrations positively correlated with the number of primordial follicles and AFC in humans [19] and cattle [15]. Although the ovarian reserve is proven to decrease as one's age progresses in humans [20], there is no report about negative correlation between the age and AFC in dairy cattle. Previous studies indicated high repeatability in the mean AFC values per follicular wave within an individual [21] and high repeatability in the maximum AFC value during successive follicular waves in an estrous cycle [22]. Also, this repeatability was confirmed to continue at least 1 year [22].

Previous studies demonstrated that cows with high AFC had higher pregnancy rates [23] and shorter calving to conception intervals [23, 24]; in addition, Mossa et al. [23] indicated higher parities in high AFC cows than in low AFC cows. These findings suggest better reproductive competence and the possibility of earlier first postpartum ovulation in high AFC cattle; however, the relationship between the postpartum resumption of an ovarian cycle and the ovarian reserve currently remains unclear.

The objective of the present study was to examine the relationships between follicular dynamics and the ovarian cycle, nutritional status, and ovarian reserve (AFC or serum AMH concentration) in postpartum cows.

\section{Methods \\ Animals}

Twenty-six Holstein dairy cows were used in the present study. Their parity was $3.0 \pm 1.6$ (mean $\pm \mathrm{SD}$; ranging from 1 to 6). They were kept in the Experimental Farm of Hokkaido University (Sapporo, Japan), which has tie stall barns and is attached to a small pasture, and were milked twice daily (9:00 and 15:30). The mean 305-day milk yield of these cows was $6419 \mathrm{~kg}$. Each cow was subjected to the experiment from calving to 70-120 DIM. Eighteen out of 26 cows were subjected to the experiment between November 2010 and October 2011 (5 primiparous cows and 13 multiparous cows). They were housed in the barn all day between November 2010 and March 2011 and fed hay, corn silage, and concentrated 
feed (beet pulp and barley, 6-8 kg). Between April and October 2011, they were pastured in the daytime and nighttime and fed corn silage and a reduced amount of concentrated feed $(1-3.5 \mathrm{~kg})$. The 8 other cows were used between February 2013 and December 2013 (2 primiparous cows and 6 multiparous cows). They were housed in the barn all day from calving to 60 DIM. They were fed corn silage and hay at $110 \%$ the amount they had the day before as roughage, and were also fed formula feed (Monster 21, Hokuren Agricultural Cooperative Association, Sapporo, Japan) $4 \mathrm{~kg} /$ day, soybean meal $2 \mathrm{~kg} /$ day, and rolled dry corn $4 \mathrm{~kg} /$ day as concentrated feed. After 61 DIM, they went under either condition: pastured daytime and nighttime or housed in the barn all day. In barn housing, cows were fed corn silage, hay, and formula feed.

VWP was set to be approximately 60 DIM, and cows were inseminated when they exhibited estrous symptoms or ovulation was considered to be upcoming based on transrectal ultrasonography after VWP.

This experiment was implemented according to the animal experimental regulations of Hokkaido University (Approval nos.: 11-0013 and 12-0027).

\section{Ovarian ultrasonography}

Transrectal ultrasonography of the ovaries was conducted by two technicians using two ultrasonographic devices, SSD-900 (ALOKA, Tokyo, Japan) with a 7.5$\mathrm{MHz}$ convex probe (UST-995-7.5, ALOKA, Tokyo, Japan) and HS-1500 (HONDA ELECTRONICS CO., LTD., Aichi, Japan) with a 10.0-MHz linear probe (HLS375MR, HONDA ELECTRONICS CO., LTD., Aichi, Japan). Scanning was conducted from 5 to 10 DIM to 70-120 DIM thrice a week (Monday, Wednesday, and Friday) in principal.

Examinations of AFC, follicular diameters, and CL formation were conducted according to procedures described by Jaiswal et al. [25]: i.e., depicted images of follicles (larger than approximately $2 \mathrm{~mm}$ in diameter) and $\mathrm{CL}$ in an ovary were sketched from the outside to inside of the ovary, and the diameters and numbers of follicles were then recorded. In the analysis of recorded ovarian images, a certain series of follicular dynamics as small follicles $(2-5 \mathrm{~mm})$ emerge, grow, are selected one by one, and reach $8.5 \mathrm{~mm}$ in diameter, and 1 or $2 \mathrm{dom}$ inant follicle(s) keep growing and result in ovulation or regression, which is defined as a follicular wave. According to previous studies [26, 27], the growth rate of follicles was calculated as $1.9 \mathrm{~mm} /$ day and the day of emergence of the follicular wave was defined as the first day that a follicle attained $4 \mathrm{~mm}$ in diameter [22, 27]. The ovulation day was selected as an intermediate day before and after the disappearance of a dominant follicle in ultrasonographic examinations. When the ultrasonographic examination was performed on 2 consecutive days and the disappearance of the dominant follicle was confirmed, the latter day was denoted as the ovulation day. Examinations of AFC were repeated from 14 to 51 times for each cow and the mean and the median AFC values in each cow was calculated.

When the largest follicle exceeded $25 \mathrm{~mm}$ in diameter and persisted for more than 10 days in the absence of CL, it was classified as a follicular cyst [28]. The data of 1 cow with a follicular cyst before the first postpartum ovulation were excluded from all analyses.

Since ovulation was not confirmed in 2 cows, the ovulation day was defined as the middle day (20 and 92 DIM) between the last observation before ovulation (15 and 86 DIM) and the first observation after CL formation (24 and 97 DIM, respectively), and their data were used in analyses.

\section{BW measurements}

BW was measured using an electronic body weight scale in a frequency from once a week to once a month. According to the methods described by Roche et al. [29], BW measured within 1 week of calving was defined as BW at calving. The BW change rate from calving to the nadir ((BW at nadir - BW at calving) / BW at calving) (\%), and the daily rate of BW changes from calving to the nadir $(\mathrm{kg} /$ day $)$ were calculated. The data of 2 cows for which BW at calving was not measured were excluded from the analysis related to BW. The data of 6 more cows that showed nadir BW at calving were excluded from the analysis of the daily rate of BW changes from calving to the nadir.

\section{Blood sampling and measurement of serum $\mathrm{AMH}$ concentrations}

The collection of blood samples and measurement of serum AMH concentrations were conducted on 18 out of 26 cows. The collection of blood samples via the caudal vein was started within 30 DIM and conducted once a month (3-4 times in 16 cows, twice in 1 cow, and once in 1 cow). The mean value of serum AMH concentrations in each cow was calculated and used in analyses. Collected samples were centrifuged at $10,000 \times g$ for 25 min and serum was then stored at $-20^{\circ} \mathrm{C}$ until assayed for $\mathrm{AMH}$.

Serum AMH concentrations were measured using AMH Gen II ELISA (A73818, BECKMAN COULTER, CA, US) and AMH Gen II Calibrators \& Control (A73819, BECKMEN COULTER). Assays were conducted in accordance with the attached instructions. This assay kit can be applied for measuring AMH in cattle as described elsewhere [30]. 


\section{Statistical analysis}

The data of 2 cows that did not ovulate in the experimental period were excluded from all analyses. The mean AFC value of each cow was used in the analyses as a representative AFC value of each cow, because they showed the positive correlation between the mean and the median AFC values in each cow $(r=0.99, P<0.0001)$ (Fig. 1). Based on the results of the mean AFC value, cows were divided into two groups according to Ireland et al. [16] with slight modifications. Although cattle were divided into three groups in the study by Ireland et al. [16] based on AFC: high ( $\geq 25)$, intermediate (16-24), and low $(\leq 15)$ groups, cows were divided into two groups in the present study: high $(\geq 25)$ and low $(<25)$ groups. One cow in the low AFC group that had its first postpartum ovulation 87 DIM after the administration of a $\mathrm{GnRH}$ analog $\left(\right.$ Conceral $^{\circ}$ injection, Intervet Co., Tokyo, Japan) was included in the analysis of the first ovulation. DIM of the first AI and days open (days from calving to AI with which pregnancy was achieved) were examined in a retrospective analysis. The data of 2 cows that were not inseminated were excluded from the analysis on DIM of the first postpartum AI, and the data of 10 cows that did not conceive by the determined cut-off date, 180 DIM [4], were excluded from the analysis of days open. The data of 1 cow that did not achieve the second ovulation in the experimental period and another 2 cows in which the exact timing of ovulation was not confirmed were excluded from the analysis on the first ovarian cycle. The average milk yield (kg/day) for 17 weeks after parturition and the peak milk yield (kg/day) were analyzed according to the method of Westwood et al. [31].

All statistical analyses were performed using JMP Pro 14.0.0 (SAS Institute Japan, Tokyo, Japan). Data were

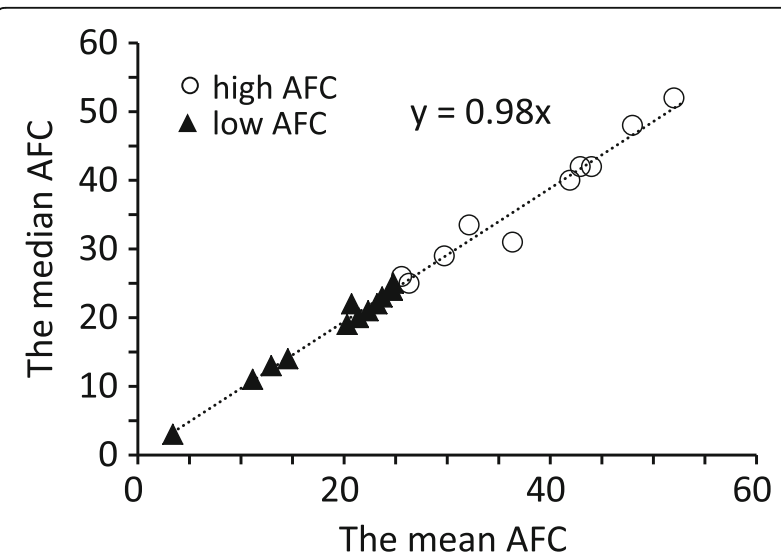

Fig. 1 Relationship between the mean and median AFC in cows $(r=0.99, P<0.0001)$. The mean and median AFC values were calculated using more than 14 samples in each cow during the experimental period presented as means $\pm \mathrm{SD}$, and also medians were shown in the data of AFC, AMH, DIM of the first postpartum ovulation, DIM of the first AI and days open. Mean values between 2 groups were compared using the Student's $t$-test, the relationships between 2 parameters were analyzed using Pearson's correlation coefficient, and $P$-values were calculated by a regression analysis.

\section{Results}

The average AFC of all cows was $27.2 \pm 12.2$ (mean \pm SD, range between 3.4 and 52.0, $n=23$ ); AFC was significantly higher in the high AFC group than in the low AFC group $(P<0.0001)$ (Table 1$)$. The average AFC of 2 cows that did not ovulate in the experimental period were 14.4 and 18.6, respectively. The parity of the cows was significantly higher in the high AFC group (3.7 \pm 1.5 , 1 primiparous and 9 multiparous cows) than in the low AFC group $(2.4 \pm 1.5,5$ primiparous and 8 multiparous cows $)(P<0.05)$, and the mean months of age were higher in the high AFC group $(70.3 \pm 25.8)$ than in the low AFC group $(47.3 \pm 21.3)(P<0.05)$. The average AFC were similar between cows examined by 2 different ultrasonographic devices, $26.7 \pm 13.9$ (SSD-900) and $28.0 \pm 9.1$ (HS-1500) $(P=0.81)$. The average serum AMH concentration in all cows was $0.17 \pm 0.14 \mathrm{ng} / \mathrm{ml}$ (range between 0.03 and $0.50, n=15$ ); AMH was higher in the high AFC group than in the low AFC group $(P<$ 0.05) (Table 1). The average AMH concentrations of 2 cows that did not ovulate in the experimental period were 0.12 and $0.11 \mathrm{ng} / \mathrm{ml}$, respectively. Variations larger than 10-fold were noted in AFC and AMH between individuals. A strong positive correlation was observed between average AFC and serum AMH concentrations in an individual $(r=0.87, P<0.0001)$ (Fig. 2). Diseases during the experimental period were hypocalcemia in 2 cows, retention of placenta in 3 cows, and mastitis in 3 cows; however, all of them were not severe and no negative effect on AFC was recognized before and after diseases.

The mean DIM of the first postpartum ovulation was $38.0 \pm 22.7$ (range between 11 and 92, $n=23$ ). The first postpartum ovulation was significantly earlier in the high

Table 1 AFC and AMH of cows in the high and low AFC groups

\begin{tabular}{lllllll}
\hline Item & AFC group & No. of cows & Mean \pm SD & Min & Median & Max \\
\hline AFC & High & 10 & $37.8 \pm 9.3^{\mathrm{a}}$ & 25.6 & 39.1 & 52.0 \\
& Low & 13 & $19.0 \pm 6.5^{\mathrm{b}}$ & 3.4 & 21.1 & 24.8 \\
$\mathrm{AMH}^{+}$ & High & 7 & $0.27 \pm 0.15^{\mathrm{a}}$ & 0.09 & 0.21 & 0.50 \\
$(\mathrm{ng} / \mathrm{ml})$ & Low & 8 & $0.09 \pm 0.06^{\mathrm{b}}$ & 0.03 & 0.06 & 0.20 \\
& &
\end{tabular}

AFC antral follicle count; $A M H$ anti-Müllerian hormone. The mean AFC value of each cow was used as a representative AFC value of each cow

${ }^{\text {ab }}$ Values with different superscripts are significantly different $(P<0.05)$

${ }^{\dagger}$ Serum AMH concentrations were not measured in 8 cows 


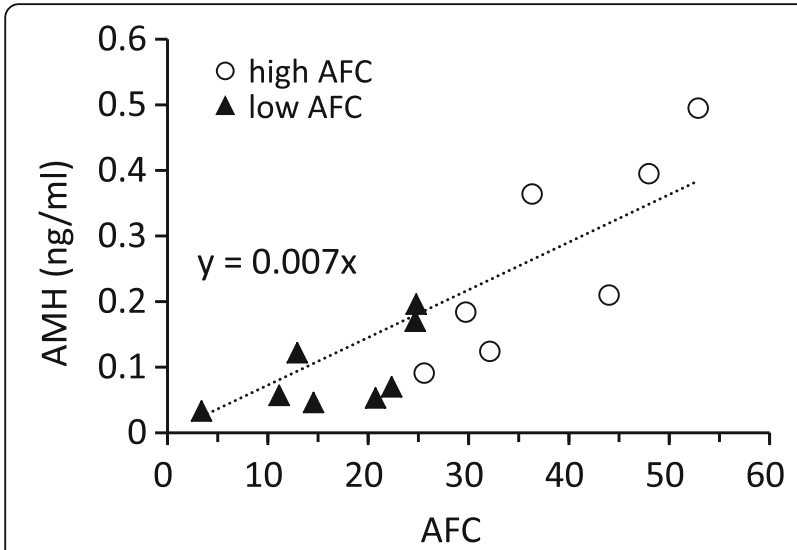

Fig. 2 Relationship between AFC and serum AMH concentrations in cows $(r=0.87, P<0.0001)$. AFC and AMH values are mean values calculated using more than 14 and 1 sample(s), respectively, in each cow during the experimental period

AFC group than in the low AFC group $(P<0.05)$ (Table 2, Fig. 3). The mean DIM of the first postpartum AI was $100.4 \pm 29.5$ (range between 55 and $160, n=21$ ), and were similar between the high and low AFC groups $(P=0.48)$. Furthermore, the mean days open was $113.2 \pm 34.7$ (range between 71 and 160, $n=13$ ), and were similar between the high and low AFC groups $(P=$ 0.08) (Table 2). In the low AFC group, all primiparous cows (5 out of 5) and 2 out of 7 multiparous cows (28.6\%) conceived before 147 DIM. On the other hand, 6 out of $9(66.7 \%)$ multiparous cows conceived before 160 DIM in the high AFC group.

The mean BW change rate (\%) from calving to the nadir in all cows was $-5.2 \pm 5.2 \%$ (range between -17.7 and $0 \%, n=21$ ), and the mean weeks after parturition in which their BW became nadir was $5.6 \pm 4.7$ weeks (range between 1 and 16 weeks). The mean BW change rates were similar between the high and low AFC groups $(P=$ $0.15)$ (Table 3), and also similar between primiparous ($8.0 \pm 5.0 \%, n=5)$ and multiparous cows $(-4.3 \pm 5.1 \%$, $n=16)(P=0.18)$. DIM of the first ovulation markedly varied in the low AFC group (from 12 to 92 DIM) regardless of BW change rate $(r=0.39, P=0.21, n=12)$,

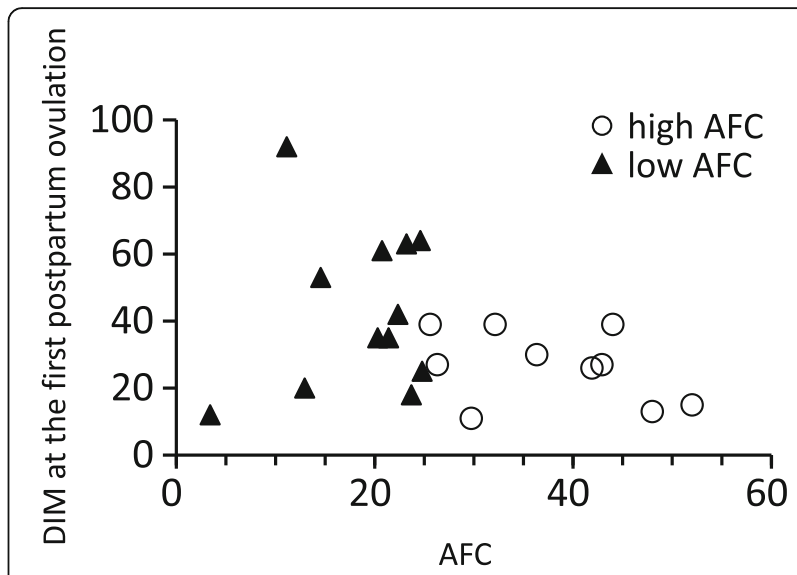

Fig. 3 Relationship between AFC and DIM at the first postpartum ovulation. A significant difference was observed in the mean DIM of the first postpartum ovulation between the high $(26.6 \pm 10.7 \mathrm{DIM}$, $n=10$; open circle symbols) and low (46.7 $\pm 25.8 \mathrm{DIM}, n=13$; solid triangle symbols) AFC groups $(P<0.05)$. AFC values were calculated using more than 14 samples in each cow during the experimental period

whereas variations in DIM of the first ovulation were smaller and first ovulation occurred earlier (range between 13 and 39 DIM) in the high AFC group regardless of BW change rate $(r=-0.14, P=0.72, n=9)$ (Fig. 4). The mean daily rate of $\mathrm{BW}$ changes from calving to the nadir in all cows was $-1.5 \pm 1.3 \mathrm{~kg} /$ day $(n=15)$ and the mean daily rates of BW changes were similar between the high and low AFC groups $(P=0.74)$. The average milk yield for 17 weeks postpartum in all cows was $26.3 \pm 5.8 \mathrm{~kg} /$ day $(n=23)$ and similar between the high and low AFC groups $(P=0.95)$ (Table 3$)$. The mean peak milk yield in all cows was $32.2 \pm 6.3 \mathrm{~kg} /$ day $(n=23)$. The mean week after parturition in which their milk production achieved their peaks was $6.6 \pm 4.0$ weeks (range between 2 and 17 weeks). The mean peak milk yields were similar between the high and low AFC groups $(P=0.89)$ (Table 3$)$.

The mean duration of the first ovarian cycle in all cows was $15.8 \pm 4.7$ days $(n=20)$. Seven cows $(2$ cows in the high AFC group and 5 cows in the low AFC group) had a

Table 2 Reproductive results of cows in the high and low AFC groups

\begin{tabular}{|c|c|c|c|c|}
\hline Days from parturition to & AFC group & No. of cows & Mean \pm SD & Median \\
\hline \multirow[t]{2}{*}{ First postpartum ovulation } & High & 10 & $26.6 \pm 10.7^{a}$ & 27 \\
\hline & Low & 13 & $46.7 \pm 25.8^{b}$ & 42 \\
\hline \multirow[t]{2}{*}{ First postpartum $\mathrm{Al}^{\dagger}$} & High & 9 & $105.8 \pm 37.2$ & 95 \\
\hline & Low & 12 & $96.3 \pm 23.1$ & 93 \\
\hline \multirow[t]{2}{*}{ Achieving pregnancy ${ }^{\ddagger}$} & High & 6 & $131.2 \pm 29.2$ & 135 \\
\hline & Low & 7 & $97.7 \pm 33.0$ & 82 \\
\hline
\end{tabular}

AFC antral follicle count; DIM days in milk; $A /$ artificial insemination

ab Values with different superscripts are significantly different $(P<0.05)$

${ }^{\dagger}$ Two cows were not inseminated

${ }^{\ddagger}$ Days of achieving pregnancy were calculated based on cows conceived by 180 DIM 
Table 3 Parameters of nutritional status of cows in the high and low AFC groups

\begin{tabular}{|c|c|c|c|}
\hline Item & AFC group & No. of cows & Mean $\pm S D$ \\
\hline \multirow[t]{2}{*}{ BW change rate ${ }^{a c}(\%)$} & High & 9 & $-3.3 \pm 3.9$ \\
\hline & Low & 12 & $-6.6 \pm 5.7$ \\
\hline \multirow[t]{2}{*}{ Daily rate of BW changes ${ }^{\text {bd }}$ (kg/day) } & High & 5 & $-1.4 \pm 0.9$ \\
\hline & Low & 10 & $-1.6 \pm 1.5$ \\
\hline \multirow[t]{2}{*}{ The average milk yield ${ }^{e}$ (kg/day) } & High & 10 & $26.4 \pm 5.7$ \\
\hline & Low & 13 & $26.2 \pm 6.2$ \\
\hline \multirow[t]{2}{*}{ The mean peak milk yield $(\mathrm{kg} /$ day) } & High & 10 & $32.0 \pm 5.4$ \\
\hline & Low & 13 & $32.4 \pm 7.2$ \\
\hline
\end{tabular}

AFC antral follicle count; $B W$ body weight

${ }^{a}$ Two cows were not measured their BW at calving

b Six cows showed nadir BW at calving

' The BW change rate from calving to the nadir; ((BW at nadir - BW at calving) / BW at calving)

${ }^{\mathrm{d}}$ Daily rate of $\mathrm{BW}$ changes from calving to the nadir

e The average milk yield was calculated by the milk yield for 17 weeks postpartum

${ }^{\mathrm{f}}$ The peak milk yield was observed from 2 to 17 weeks postpartum

first ovarian cycle that was shorter than 12 days, with 6 (1 cow in the high AFC group and 5 cows in the low AFC group) showing only one follicular wave in the first ovarian cycle. Twelve out of 12 cows with the first postpartum ovulation within 35 DIM had a first ovarian cycle that was longer than 17 days, and 7 out of 8 cows with the first ovulation after 39 DIM had a first ovarian cycle that was shorter than 12 days (Fig. 5). A strong negative correlation was observed between DIM of the first postpartum ovulation and the duration of the first ovarian cycle $(r=-0.78$, $P<0.0001)$. The mean duration of the first ovarian cycle was similar between the high AFC group (17.2 \pm 4.7 days, $n=10)$ and low AFC group $(14.4 \pm 4.5$ days, $n=10)(P=$ $0.19)$; however, all cows with the first ovulation after 42 DIM belonged to the low AFC group, and had a first ovarian cycle that was shorter than 12 days (Fig. 5).

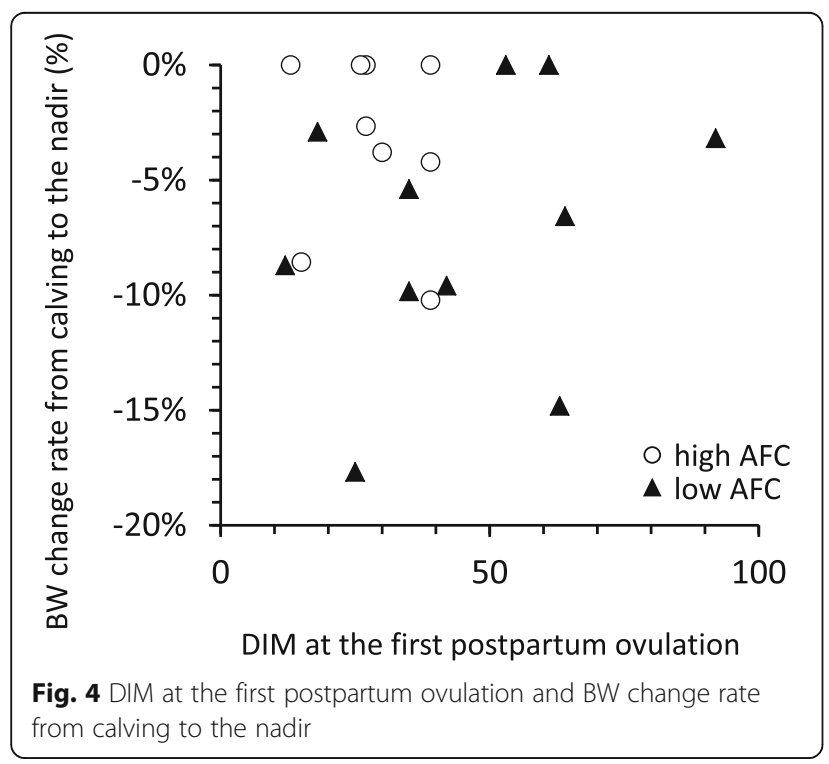

\section{Discussion}

The first postpartum ovulation was significantly earlier in high AFC cows than in low AFC cows in the present study. Mossa et al. [23] previously reported that cows with low AFC $(\leq 15)$ have lower pregnancy rates and longer calving to conception intervals. The present results support these findings. Cows with low AFC are at a higher risk of delayed first postpartum ovulation, resulting in a greater risk of the delayed resumption of estrous symptoms and AI.

Changes in BW and milk production were used as indicators of nutritional status in the present study, and the interactions between the ovarian reserve and nutritional status to postpartum follicular dynamics and the ovarian cycle were investigated. Cows in different AFC groups showed a similar nutritional status; however, they showed different timing for the first postpartum ovulation; i.e., the timing of the first postpartum ovulation was early (from 13 to 39 DIM) in high AFC cows and largely varied (from 12 to 92 DIM) in low AFC cows. In

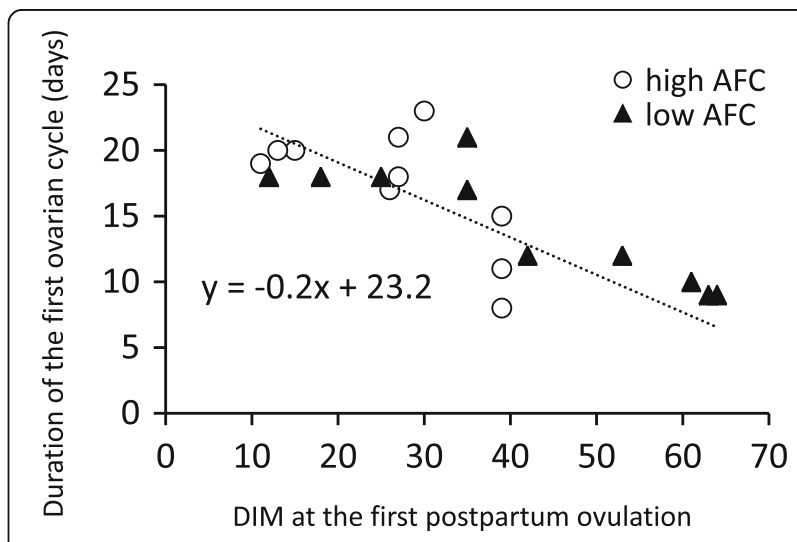

Fig. 5 Relationship between DIM at the first postpartum ovulation and duration of the first ovarian cycle $(r=-0.78, P<0.0001)$ 
the present study, BW decreased but milk production increased in each group. It means that they were in undernutrition condition and assumed to be in NEB status. These results suggest the ovarian reserve is an important regulatory factor controlling the timing of the first ovulation under NEB status. In further study, we should evaluate dry matter intake and metabolic status to evaluate the relationships between energy balance, ovarian reserve, and reproductive parameters more precisely. In addition, we used the dairy herd in which cows showed lower milk yield (6419 $\mathrm{kg}$ per 305 days in average) than average dairy cows in Japan (9601 kg per 305 days, 2016, Livestock Improvement Association of Japan, Inc.); therefore, we should examine the effects of the different ovarian reserves on reproductive parameters in higher yielding cows in future.

Previous studies reported that failed postpartum ovulation was due to an insufficient LH pulse frequency and lower estradiol production, and that NEB was a major factor responsible for this phenomenon [2, 7]. On the other hand, lower pulsatile LH secretion and higher sensitivity to LH in high AFC cattle were shown in recent studies; although high AFC cattle showed a lower LH pulse amplitude than low AFC cattle in the luteal phase [32], the circulating concentration of testosterone, which is produced in theca cells by an LH stimulus, was higher in high AFC cattle [33]. In addition, high AFC cattle showed higher intrafollicular androstenedione and estradiol concentrations in preovulatory follicles [33]. In a previous study, the effect of testosterone on the early follicular development was also reported; exogenous testosterone increased the number of secondary follicles [34]. These findings prompted us to speculate that the earlier first postpartum ovulation in high AFC cows in the present study was attributed to inherently higher sensitivity to $\mathrm{LH}$ than frequent $\mathrm{LH}$ pulses. In future studies, we need to investigate the frequency of LH pulses and expression of $\mathrm{LH}$ receptors in the dominant follicle in cows with different AFC.

The mean DIM of the first postpartum ovulation was previously reported to be 27.4 [35] and 30.9 [4]. Although the mean DIM of the first ovulation in all cows in the present study was 38.0 and later than those reported previously, mean DIM of the first ovulation was 26.6 in the high AFC group, which was consistent with previous findings. Previous studies reported that cows with an earlier first postpartum ovulation were subjected to significantly earlier first AI [36] and showed shorter days open [13, 36]. In contrast to these studies, the DIM of the first postpartum $\mathrm{AI}$ and mean days open were similar between the high and low AFC groups in the present study, in spite of the earlier first postpartum ovulation in high AFC cows. A reason for this may be that most cows (18 out of 23 cows) showed the first postpartum ovulation before VWP (60 DIM). In addition, the ovarian cycles of each cow were constantly examined by ultrasonography, and AI was performed regardless of the presence of obvious estrous behavior. Therefore, the frequent diagnosis of the ovarian status by ultrasonography may enhance the pregnancy of low AFC cows. Furthermore, higher ratio of multiparous cows conceived in high AFC group (6 out of 9, 66.7\%) compared to low AFC group ( 2 out of 7, 28.6\%), although days open were similar between high and low AFC groups. There is a possibility of high fertility especially in multiparous high AFC cows. In further study, we should examine the relationships between AFC, cow fertility, and the effect of frequent diagnosis by ultrasonography by the evaluation of more cows and different dairy herds.

Cows with a later first postpartum ovulation showed a shorter first ovarian cycle. This result was consistent with previous findings, which indicated that a short first ovarian cycle was frequently observed in dairy cows with the first ovulation later than 3 weeks postpartum [36, 37]. In the present study, cows with the first ovulation after 42 DIM $(n=5)$ belonged to the low AFC group and had a first ovarian cycle that was shorter than 12 days. These results suggest that low AFC cows have higher rates of a delayed first ovulation and short first ovarian cycle, leading to the delayed resumption of fertility, than high AFC cows. In a previous study on beef cows, a short first cycle was preceded by less frequent LH pulses and lower estradiol production during the first postpartum ovulatory growing phase [38]. The present results also indicate that low AFC cows have lower sensitivity to an LH stimulus and/or higher sensitivity to undernutrition condition than high AFC cows.

\section{Conclusions}

The present study confirmed that first postpartum ovulation was earlier in cows with high AFC than in those with low AFC in undernutrition condition. Furthermore, cows with low AFC appear to be at a greater risk of delayed first postpartum ovulation and a short first ovarian cycle after the first postpartum ovulation, resulting in the delayed resumption of fertility, than cows with high AFC. However, frequent examinations of the ovarian cycles by ultrasonography may help earlier AI performance and pregnancy even in cows with delayed first postpartum ovulation. These results indicate that the ovarian reserve exerts strong regulatory effects on the timing of the first ovulation. 


\section{Abbreviations}

AFC: Antral follicle count; Al: Artificial insemination; AMH: Anti-Müllerian hormone; BCS: Body condition score; BW: Body weight; CL: Corpus luteum; DIM: Days in milk; FSH: Follicle-stimulating hormone; GnRH: Gonadotropinreleasing hormone; LH: Luteinizing hormone; NEB: Negative energy balance; WP: Voluntary waiting period

\section{Acknowledgments}

We thank the members in the Experimental Farm of Hokkaido University for their technical assistance in animal handling, and the members in the Laboratory of Animal Production System for their technical assistance in data collecting. We also thank the members in the Laboratory of Theriogenology for their various technical assistance. This manuscript was edited by Medical English Service, Kyoto, Japan.

\section{Authors' contributions}

EF carried out experimental work, conducted the statistical analysis, and wrote the manuscript. TM carried out the ovarian ultrasonography and analyzed data. KS guided the interpretation of data. MB measured body weight and analyzed data. YY carried out blood sampling and hormone measuring, and revised the manuscript. KU revised the manuscript. MN supervised all aspects of this study, and wrote the manuscript. All authors read and approved the final manuscript.

\section{Funding}

This work was supported by JSPS KAKENHI Grant Numbers JP16K08043 and JP19H03117 to Masashi Nagano.

\section{Availability of data and materials}

The datasets used and/or analyzed during the present study are available from the corresponding author on reasonable request.

\section{Ethics approval and consent to participate}

This study was approved by the Institutional Animal Care and Use Committee of Hokkaido University. (Approval nos.: 11-0013 and 12-0027)

\section{Consent for publication}

Not applicable.

\section{Competing interests}

The authors declare that they have no competing interests.

\section{Author details}

'Laboratory of Theriogenology, Graduate School of Veterinary Medicine, Hokkaido University, Sapporo 060-0818, Japan. ²Laboratory of Animal Production System, Graduate School of Agriculture, Hokkaido University, Sapporo 060-8589, Japan. ${ }^{3}$ Laboratory of Theriogenology, Faculty of Veterinary Medicine, Hokkaido University, Sapporo 060-0818, Japan. ${ }^{4}$ Laboratory of Animal Production System, Research Faculty of Agriculture, Hokkaido University, Sapporo 060-8589, Japan. ${ }^{5}$ Laboratory of Animal Reproduction, Department of Animal Science, School of Veterinary Medicine, Kitasato University, Towada 034-8628, Japan.

Received: 19 August 2019 Accepted: 6 January 2020

Published online: 11 January 2020

\section{References}

1. Beam SW, Butler WR. Energy balance and ovarian follicle development prior to the first ovulation postpartum in dairy cows receiving three levels of dietary fat. Biol Reprod. 1997;56(1):133-42.

2. Beam SW, Butler WR. Effects of energy balance on follicular development and first ovulation in postpartum dairy cows. J Reprod Fertil Suppl. 1999;54: $411-24$

3. Sakaguchi M. Oestrous expression and relapse back into anoestrus at early postpartum ovulations in fertile dairy cows. Vet Rec. 2010;167(12):446-50.

4. Sakaguchi M, Sasamoto Y, Suzuki T, Takahashi Y, Yamada Y. Postpartum ovarian follicular dynamics and estrous activity in lactating dairy cows. $J$ Dairy Sci. 2004;87(7):2114-21.

5. Crowe MA. Resumption of ovarian cyclicity in post-partum beef and dairy cows. Reprod Domest Anim. 2008;43(Suppl 5):20-8.
6. Wathes DC, Fenwick M, Cheng Z, Bourne N, Llewellyn S, Morris DG, et al. Influence of negative energy balance on cyclicity and fertility in the high producing dairy cow. Theriogenology. 2007;68(Suppl 1):S232-41.

7. Cheong SH, Sa Filho OG, Absalon-Medina VA, Pelton SH, Butler WR, Gilbert RO. Metabolic and endocrine differences between dairy cows that do or do not ovulate first postpartum dominant follicles. Biol Reprod. 2016;94(1):18

8. Senatore E, Butler W, Oltenacu P. Relationships between energy balance and post-partum ovarian activity and fertility in first lactation dairy cows. Anim Sci. 1996;62(1):17-23.

9. Sakaguchi M. Differences between body condition scores and body weight changes in postpartum dairy cows in relation to parity and reproductive indices. Can Vet J. 2009:50(6):649-56.

10. Roche JF, Mackey D, Diskin MD. Reproductive management of postpartum cows. Anim Reprod Sci. 2000;60-61:703-12.

11. Ribeiro ES, Lima FS, Greco LF, Bisinotto RS, Monteiro AP, Favoreto M, et al Prevalence of periparturient diseases and effects on fertility of seasonally calving grazing dairy cows supplemented with concentrates. J Dairy Sci. 2013:96(9):5682-97.

12. Santos JE, Rutigliano HM, Sa Filho MF. Risk factors for resumption of postpartum estrous cycles and embryonic survival in lactating dairy cows. Anim Reprod Sci. 2009;110(3-4):207-21.

13. Walsh RB, Kelton DF, Duffield TF, Leslie KE, Walton JS, LeBlanc SJ. Prevalence and risk factors for postpartum anovulatory condition in dairy cows. J Dairy Sci. 2007;90(1):315-24.

14. Broekmans FJ, Kwee J, Hendriks DJ, Mol BW, Lambalk CB. A systematic review of tests predicting ovarian reserve and IVF outcome. Hum Reprod Update. 2006;12(6):685-718.

15. Ireland JJ, Smith GW, Scheetz D, Jimenez-Krassel F, Folger JK, Ireland JL, et al. Does size matter in females? An overview of the impact of the high variation in the ovarian reserve on ovarian function and fertility, utility of anti-Mullerian hormone as a diagnostic marker for fertility and causes of variation in the ovarian reserve in cattle. Reprod Fertil Dev. 2011;23(1):1-14.

16. Ireland $J$, Scheetz D, Jimenez-Krassel F, Themmen AP, Ward F, Lonergan $P$, et al. Antral follicle count reliably predicts number of morphologically healthy oocytes and follicles in ovaries of young adult cattle. Biol Reprod. 2008;79(6):1219-25.

17. Durlinger AL, Kramer P, Karels B, de Jong FH, Uilenbroek JT, Grootegoed JA, et al. Control of primordial follicle recruitment by anti-Mullerian hormone in the mouse ovary. Endocrinology. 1999;140(12):5789-96.

18. Rico C, Medigue C, Fabre S, Jarrier P, Bontoux M, Clement F, et al. Regulation of anti-Mullerian hormone production in the cow: a multiscale study at endocrine, ovarian, follicular, and granulosa cell levels. Biol Reprod. 2011;84(3):560-71.

19. Visser JA, de Jong FH, Laven JS, Themmen AP. Anti-Mullerian hormone: a new marker for ovarian function. Reproduction. 2006:131(1):1-9.

20. de Vet A, Laven JS, de Jong FH, Themmen AP, Fauser BC. Antimullerian hormone serum levels: a putative marker for ovarian aging. Fertil Steril. 2002;77(2):357-62

21. Ireland JJ, Ward F, Jimenez-Krassel F, Ireland JL, Smith GW, Lonergan P, et al. Follicle numbers are highly repeatable within individual animals but are inversely correlated with FSH concentrations and the proportion of goodquality embryos after ovarian stimulation in cattle. Hum Reprod. 2007;22(6): 1687-95.

22. Burns DS, Jimenez-Krassel F, Ireland JL, Knight PG, Ireland JJ. Numbers of antral follicles during follicular waves in cattle: evidence for high variation among animals, very high repeatability in individuals, and an inverse association with serum follicle-stimulating hormone concentrations. Biol Reprod. 2005;73(1):54-62.

23. Mossa F, Walsh SW, Butler ST, Berry DP, Carter F, Lonergan P, et al. Low numbers of ovarian follicles $\geq 3 \mathrm{~mm}$ in diameter are associated with low fertility in dairy cows. J Dairy Sci. 2012;95(5):2355-61.

24. Quail LK, Mund ME, Neuendorff DA, Banta JP, Welsh TH Jr, Randel RD. Relationships between numbers of antral follicles and postpartum interval in Brahman females. Theriogenology. 2018;121:1-6.

25. Jaiswal RS, Singh J, Adams GP. Developmental pattern of small antral follicles in the bovine ovary. Biol Reprod. 2004;71(4):1244-51.

26. Bergfelt DR, Kulick $\amalg$, Kot $K$, Ginther OJ. Follicular and hormonal response to experimental suppression of FSH during follicle deviation in cattle. Theriogenology. 2000;54(8):1191-206. 
27. Ginther OJ, Kot K, Kulick LJ, Wiltbank MC. Emergence and deviation of follicles during the development of follicular waves in cattle.

Theriogenology. 1997;48(1):75-87.

28. Garverick HA. Ovarian follicular cysts in dairy cows. J Dairy Sci. 1997;80(5): 995-1004.

29. Roche JR, Macdonald KA, Burke CR, Lee JM, Berry DP. Associations among body condition score, body weight, and reproductive performance in seasonal-calving dairy cattle. J Dairy Sci. 2007;90(1):376-91.

30. El-Sheikh Ali H, Kitahara G, Takahashi T, Mido S, Sadawy M, Kobayashi I, et al. Plasma anti-Mullerian hormone profile in heifers from birth through puberty and relationship with puberty onset. Biol Reprod. 2017;97(1):153-61.

31. Westwood CT, Lean IJ, Garvin JK. Factors influencing fertility of Holstein dairy cows: a multivariate description. J Dairy Sci. 2002;85(12):3225-37.

32. Jimenez-Krassel F, Folger JK, Ireland JL, Smith GW, Hou X, Davis JS, et al. Evidence that high variation in ovarian reserves of healthy young adults has a negative impact on the corpus luteum and endometrium during estrous cycles in cattle. Biol Reprod. 2009;80(6):1272-81.

33. Mossa F, Jimenez-Krassel F, Folger JK, Ireland JL, Smith GW, Lonergan P, et al. Evidence that high variation in antral follicle count during follicular waves is linked to alterations in ovarian androgen production in cattle. Reproduction. 2010;140(5):713-20.

34. Yang MY, Fortune JE. Testosterone stimulates the primary to secondary follicle transition in bovine follicles in vitro. Biol Reprod. 2006;75(6):924-32.

35. Savio JD, Boland MP, Hynes N, Roche JF. Resumption of follicular activity in the early post-partum period of dairy cows. J Reprod Fertil. 1990;88(2):569-79.

36. Kawashima C, Kaneko E, Amaya Montoya C, Matsui M, Yamagishi N, Matsunaga $\mathrm{N}$, et al. Relationship between the first ovulation within three weeks postpartum and subsequent ovarian cycles and fertility in high producing dairy cows. J Reprod Dev. 2006;52(4):479-86.

37. Savio JD, Boland MP, Roche JF. Development of dominant follicles and length of ovarian cycles in post-partum dairy cows. J Reprod Fertil. 1990; 88(2):581-91.

38. Garcia-Winder M, Lewis PE, Deaver DR, Smith VG, Lewis GS, Inskeep EK. Endocrine profiles associated with life span of induced corpora lutea in postpartum beef cows. J Anim Sci. 1986;62(5):1353-62.

\section{Publisher's Note}

Springer Nature remains neutral with regard to jurisdictional claims in published maps and institutional affiliations.

Ready to submit your research? Choose BMC and benefit from:

- fast, convenient online submission

- thorough peer review by experienced researchers in your field

- rapid publication on acceptance

- support for research data, including large and complex data types

- gold Open Access which fosters wider collaboration and increased citations

- maximum visibility for your research: over $100 \mathrm{M}$ website views per year

At BMC, research is always in progress.

Learn more biomedcentral.com/submissions 